\title{
DATASET ON MAPPING AND MORPHOMETRY OF SAND DUNES IN NUBRA AND SHYOK VALLEYS, LADAKH HIMALAYA, INDIA
}

\section{NEELRATAN SINGH ${ }^{\mathrm{a} 1}$, SHAKIR ALI ${ }^{\mathrm{b}}$, N.J. RAJU ${ }^{\mathrm{c}}$, YAMUNA SINGH ${ }^{\mathrm{d}}$, KUSHAGRA RAJENDRA ${ }^{\mathrm{e}}$, MUKESH KUMAR ${ }^{\mathrm{f}}$, BENIDHAR DESHMUKH ${ }^{\mathrm{g}}$, D.C. JHARIYA ${ }^{\mathrm{h}}$, VINESH KUMAR ${ }^{\mathrm{i}}$, M.C. SHARMA $^{\mathrm{j}}$ ELORA CHAKRABORTY ${ }^{k}$, M.A. SIDDIQUI ${ }^{1}$ AND AKHILESH SINGH ${ }^{\mathrm{m}}$}

\author{
${ }^{\mathrm{ac}}$ School of Environmental Sciences, JNU, New Delhi, India \\ ${ }^{\mathrm{b}}$ Department of Geology, University of Delhi, Delhi, India \\ ${ }^{\mathrm{d}}$ Atomic Mineral Division, Hyderabad, India \\ eAmity School of Earth and Environmental Sciences, Amity University Gurgaon, Maneasar, Gurgaon, India \\ ${ }^{\mathrm{f}} \mathrm{School}$ of Agriculture, IGNOU, New Delhi, India \\ ${ }^{\mathrm{g}}$ School of Science, IGNOU, New Delhi, India \\ ${ }^{\mathrm{h}}$ Department of Applied Geology, NIT Raipur, Raipur, Chhattisgarh, India

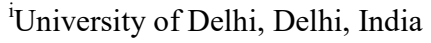 \\ ${ }^{\mathrm{j}} \mathrm{CSRD}, \mathrm{JNU}$, New Delhi \\ ${ }^{k}$ Department of Geography, Delhi School of Economics, University of Delhi, Delhi, India \\ ${ }^{\mathrm{l}}$ Department of Geography, Jamia Milia Islamia, New Delhi, India \\ ${ }^{\mathrm{m}}$ Indian Institute of Coal Management, Ranchi, Jharkhand, India
}

\begin{abstract}
Ladakh Himalaya is a cold desert having an average height of more than $3000 \mathrm{~m}$ above mean sea level. The Nubra and Shyok are the two prominent valleys located in the Ladakh Himalaya, India. During the course of field traverses clusters of many sand dunes have been observed along the courses of Nubra and Shyok Rivers. However, sand dune occurrences are restricted to certain parts along the courses of both the rivers. For example, sand dunes tend to occur in and around the granitic suite of rocks. XRD of sediments suggests that these granites are the provenance of these sand dunes. Results of mapping and morphometric studies suggest that the formation of sand dunes in the Nubra and Shyok Valleys are mainly controlled by surrounding rocks coupled with various geomorphic processes, viz., fluvial, glacial and aeolian. Among these geomorphic processes, aeolian agent appeared to have played major role in formation of sand dunes. This study deals with mapping and morphometry of these sand dunes located in both the valleys.
\end{abstract}

KEYWORDS: Sanddunes, Sand Dunes in India, Nubra and Shyok Valleys, Cold Desert, Ladakh, India

Various geomorphic processes such as aeolian, fluvial and glacial has significant role in modifying landscapes and shaping the surface of the earth on local to regional scales (Derbyshire and Owen, 2017). Further, the interaction among aeolian, fluvial and glacial processes can significantly modified earth surface morphology. Globally, various researchers have also identified the importance of fluvial and aeolian interactions, but there is limited work to understand these interactions and the associated evolution of landscapes (Liu, 2015, 2005) (Bullard, 2002, 2003).

The Quaternary basin of Ladakh Himalaya is composed predominantly of sediments having lacustrine, fluvial and glacial origins. Tectonics and prevailing climatic conditions are known to have played an important role in the formation of these basins (Bagati and Thakur, 1993).
The dominance of aeolian process over other processes is apparent in these areas, which is revealed by occurrences of several patches of sand dunes in the Nubra Valley and Shyok Valley during field traverses. Sand dunes occur in clusters along the courses of Nubra and Shyok Rivers. Their occurrences are restricted to selected parts along the course of both the rivers. These dunes have variable shapes and sizes. The results of mapping and morphometric studies on sand dunes are presented in this article involving extensive field work and use of google earth images.

\section{LOCATION OF STUDY AREA}

Nubra and Shyok Valleys are located in Ladakh Himalaya. The area is located in tectonically active zone. The Nubra Valley is a tri-armed valley located to the north east of Diskit town (Figure 1). The River Nubra forming the

${ }^{1}$ Corresponding author 
Nubra valley is a tributary of the Shyok River, which drains the Nubra region of Leh and finally joins Indus River in the east of Skardu in Pakistan. The Nubra River joins Shyok River which bifurcates into a large valley that distinguishes the Karakoram ranges from Leh. The Shyok River, a tributary of the Indus River, originates from the Rimo Glacier, one of the tongues of Siachen Glacier.

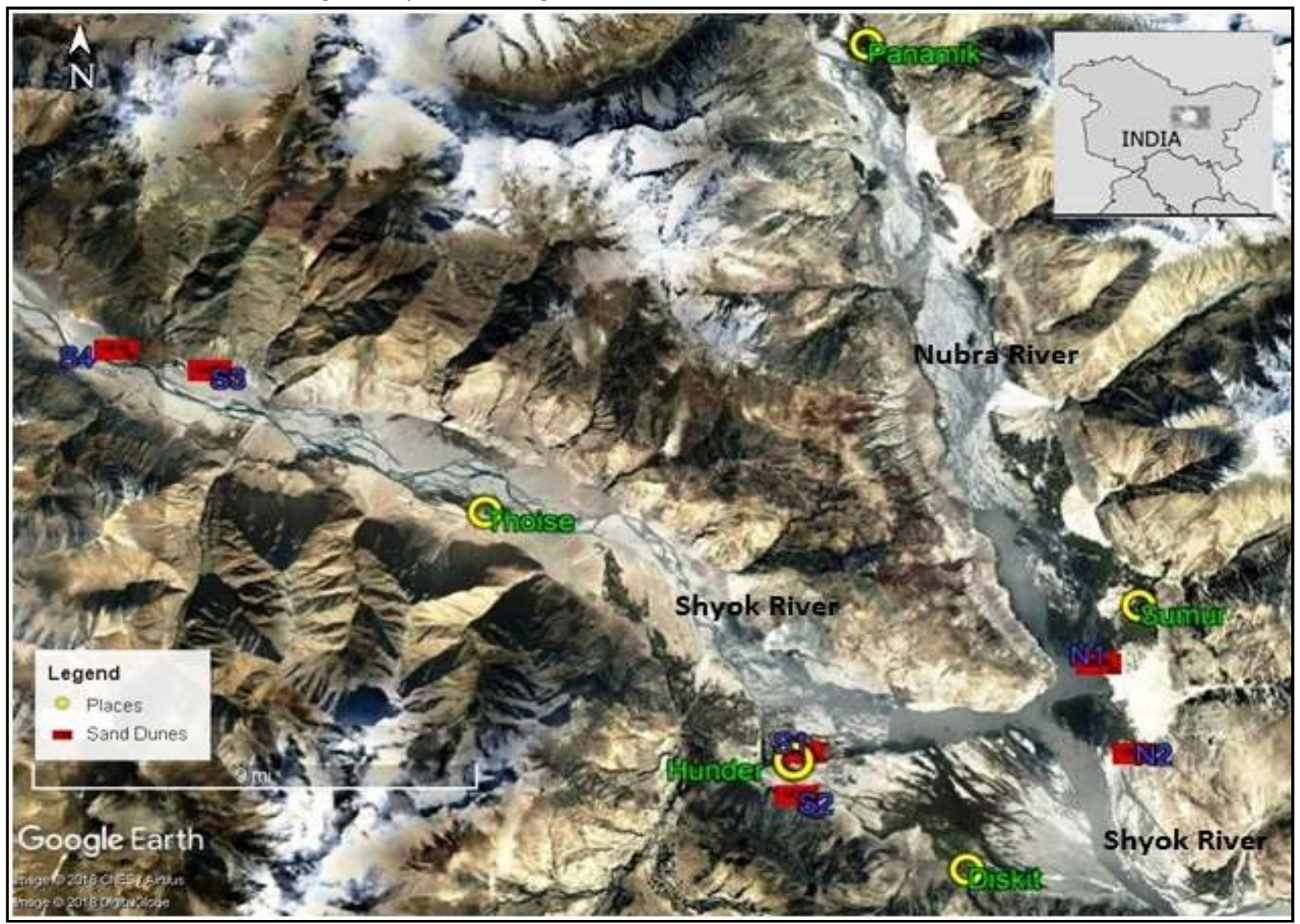

Figure 1: Location of Nubra and Shyok sand dunes on satellite image (Google Earth)

In fact, the Nubra and Shyok valleys represent high altitude cold desert regions with rare records of precipitation and scanty vegetation, except at some sporadic places which supports green cover along river beds.

\section{MATERIALS AND METHODS}

\section{Mapping and Morphometry of Sand Dunes}

Detailed morphological mapping of sand dunes (SD) of both the valleys were done using global positioning system (GPS) and by taking critical field traverses along and across the sand dune bodies during two consecutive years, i.e., $2016 \& 2017$. For marking locations of SD, GPS was used, whereas for detailed mapping of SD, Google earth image and its tools were used. The various parameters of SD, namely, length, breath, height and perimeter, were worked outseparately for both the Nubra and Shyok valleys. The identification and morphometric studies of SD carried out at various locations along the Nubra and Shyok Valleys are shown in Figure 1, and their details are given in Table 1. The patches where SD were studied are named as N1, N2, S1, S2, S3 and S4 (Table 1). The classification of SD was done by following the guidelines given by Lancaster (2001) and Hatano and Hatano (2001).

\section{Bulk Mineralogy}

$\mathrm{X}$-ray diffraction (XRD) technique was used to study the mineralogy of sand dunes for deciphering the probable source rock. For this purpose, sands from sand dunes were collected by removing the upper surface from the depth of half feet. 
Table 1: Locations of patches of sand dunes along Nubra and Shyok valleys

\begin{tabular}{|c|c|c|c|}
\hline Patch & Latitude & Longitude & Place/River \\
\hline N1 & $34^{\circ} 36^{\prime} 20.62^{\prime \prime} \mathrm{N}$ & $77^{\circ} 36^{\prime} 26.79^{\prime \prime} \mathrm{E}$ & Along Nubra River, Nubra Valley \\
\hline N2 & $34^{\circ} 34^{\prime} 40.89^{\prime \prime} \mathrm{N}$ & $77^{\circ} 37^{\prime} 11.56^{\prime \prime} \mathrm{E}$ & Along Nubra River, Nubra Valley \\
\hline S1 & $34^{\circ} 34^{\prime} 41.43^{\prime \prime} \mathrm{N}$ & $77^{\circ} 30^{\prime} 6.24^{\prime \prime} \mathrm{E}$ & Along Shyok River \\
\hline S2 & $34^{\circ} 33^{\prime} 53.65^{\prime \prime} \mathrm{N}$ & $77^{\circ} 30^{\prime} 0.51^{\prime \prime} \mathrm{E}$ & Along Shyok River \\
\hline S3 & $34^{\circ} 41^{\prime} 48.01^{\prime \prime} \mathrm{N}$ & $77^{\circ} 17^{\prime} 22.71^{\prime \prime} \mathrm{E}$ & Along Shyok River \\
\hline S4 & $34^{\circ} 42^{\prime} 11.65^{\prime \prime} \mathrm{N}$ & $77^{\circ} 15^{\prime} 21.15^{\prime \prime} \mathrm{E}$ & Along Shyok River \\
\hline
\end{tabular}

\section{RESULTS AND DISCUSSION}

\section{Sand Dunes Along the Nubra River}

The SD were observed at two places, i.e., N1 and N2 (Figure 2). The morphometric parameters of sand dunes, measured by Google Image, are given in Table 2 and Table
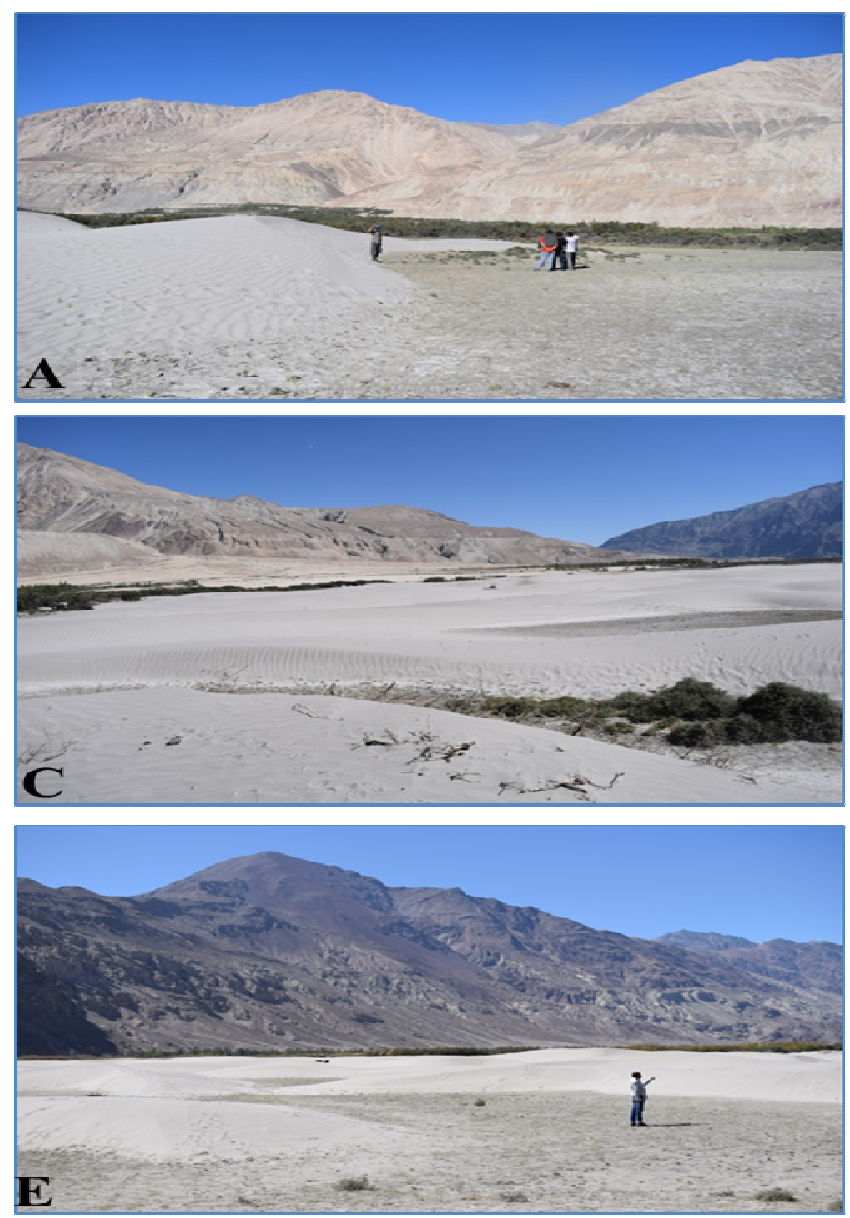

3. The length of sand dunes at N1, where they occur in clusters, ranges from 8.54 to $49.44 \mathrm{~m}$ and breath from 17.55 to $367.47 \mathrm{~m}$, while their height ranges from 0.33 to $29 \mathrm{~m}$ (Table 2). At N2, only one longitudinal sand dune was observed having $388.69 \mathrm{~m}$ length, $1245.77 \mathrm{~m}$ width and $32.8 \mathrm{~m}$ height (Table 3 ).

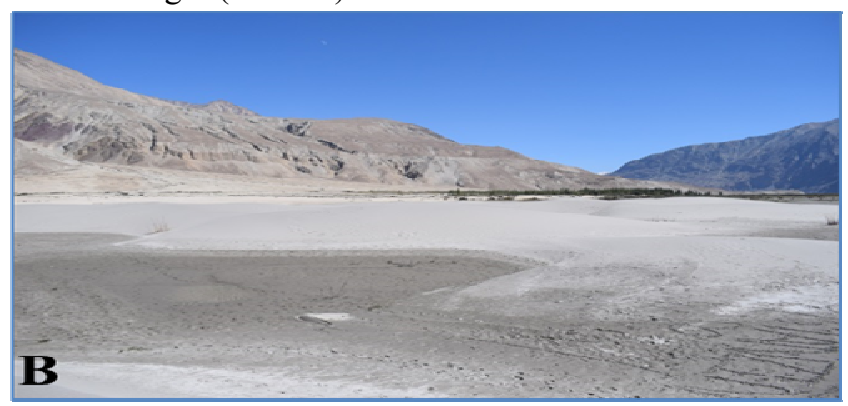

D

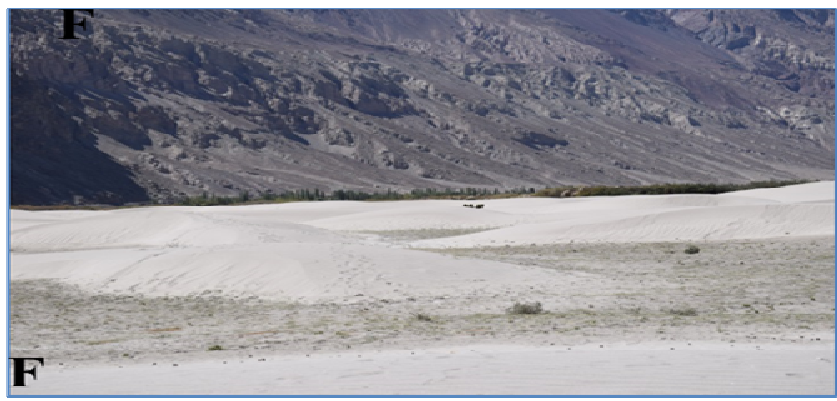

Figure 2: Sand Dunes along Nubra River (A) Morphologically crescent shape. with well defined leeward direction (B) Barchanoid Sand Dunes (C) Barchnoid Sand Dunes (D) Wind Ripple Marks on Sand Dunes (E) Sand Carpating in foot hills (F) Various Barchanoid Sand Dunes 
Table 2: Morphometric data of sand dunes observed along Nubra Valley at N1

\begin{tabular}{|c|c|c|c|c|c|c|}
\hline $\begin{array}{l}\text { Sl. } \\
\text { No. }\end{array}$ & $\begin{array}{l}\text { Length } \\
\text { (m) }\end{array}$ & $\begin{array}{c}\text { Wridth } \\
\text { (m) }\end{array}$ & $\begin{array}{c}\text { Height } \\
\text { (m) }\end{array}$ & $\begin{array}{c}\text { Area } \\
(\mathrm{Sq} \mathbf{m})\end{array}$ & $\begin{array}{c}\text { Perimeter } \\
\text { (m) }\end{array}$ & Type \\
\hline 1 & 14.8 & 20.64 & 0.33 & 191 & 57 & Disturbed Barchan due to River \\
\hline 2 & 12.2 & 21.72 & 1.33 & 211 & 60 & Disturbed Barchan due to River \\
\hline 3 & 8.99 & 21.24 & 3.67 & 168 & 50 & Disturbed Barchan due to River \\
\hline 4 & 11.04 & 37.63 & 2.00 & 386 & 91 & Barchan \\
\hline 5 & 9.75 & 25.74 & 1.00 & 218 & 66 & Barchan \\
\hline 6 & 12.05 & 66.98 & 10.67 & 725 & 173 & Barchanoid \\
\hline 7 & 24.82 & 69.94 & 10.00 & 920 & 175 & Barchanoid \\
\hline 8 & 11.62 & 17.55 & 0.67 & 164 & 48 & Disturbed Barchan due to River \\
\hline 9 & 8.54 & 18.1 & 0.67 & 135 & 46 & Disturbed Barchan due to River \\
\hline 10 & 20.73 & 65.92 & 4.00 & 837 & 153 & Disturbed Barchan due to River and Man Activities \\
\hline 11 & 12.52 & 101.01 & 16.33 & 1209 & 224 & Barchanoid \\
\hline 12 & 13.69 & 57.59 & 3.67 & 677 & 130 & Barchanoid \\
\hline 13 & 11.03 & 51.69 & 2.67 & 557 & 132 & Barchanoid \\
\hline 14 & 20.65 & 198.65 & 22.67 & 2,757 & 455 & Barchanoid \\
\hline 15 & 15.42 & 83.68 & 13.33 & 1229 & 205 & Barchanoid \\
\hline 16 & 11.51 & 58.87 & 4.67 & 589 & 148 & Barchanoid \\
\hline 17 & 49.44 & 60.33 & 19.67 & 2,082 & 255 & Barchanoid \\
\hline 18 & 15.77 & 173.71 & 23.00 & 2,276 & 395 & Barchanoid \\
\hline 19 & 12.17 & 48.73 & 23.00 & 649 & 131 & Barchanoid \\
\hline 20 & 23.04 & 257.34 & 23.00 & 3,812 & 584 & Barchanoid \\
\hline 21 & 17.06 & 180.88 & 23.67 & 3,296 & 444 & Barchanoid \\
\hline 22 & 21.27 & 70.51 & 20.00 & 994 & 168 & Barchanoid \\
\hline 23 & 16.62 & 65.15 & 8.67 & 793 & 157 & Barchanoid \\
\hline 24 & 45.69 & 50.62 & 16.33 & 1333 & 205 & Barchanoid \\
\hline 25 & 17.46 & 51.12 & 11.67 & 606 & 135 & Barchanoid \\
\hline 26 & 13.03 & 61.64 & 17.67 & 849 & 156 & Barchanoid \\
\hline 27 & 26.71 & 258.57 & 24.67 & 4,161 & 600 & Barchanoid \\
\hline 28 & 20.91 & 220.74 & 25.00 & 4,050 & 504 & Barchanoid \\
\hline 29 & 14.18 & 81.35 & 21.33 & 974 & 197 & Barchanoid \\
\hline 30 & 34 & 286.98 & 29.00 & 4,573 & 702 & Barchanoid \\
\hline 31 & 15.25 & 62.26 & 23.67 & 691 & 149 & Barchanoid \\
\hline 32 & 26.88 & 367.47 & 25.00 & 5,567 & 859 & Barchanoid affected by Vegetation Cover \\
\hline 33 & 33.91 & 242.8 & 28.00 & 4,349 & 597 & Barchanoid \\
\hline 34 & 25.12 & 202.17 & 22.00 & 3,781 & 492 & Barchanoid \\
\hline 35 & 13.82 & 51.65 & 21.33 & 647 & 128 & Barchanoid \\
\hline 36 & 15.32 & 121.18 & 20.67 & 1,548 & 266 & Barchanoid \\
\hline 37 & 20.03 & 343.36 & 17.33 & 6,429 & 799 & Barchanoid \\
\hline 38 & 19.7 & 118.64 & 15.00 & 1,303 & 254 & Barchanoid \\
\hline 39 & 29.47 & 141.92 & 10.67 & 2,122 & 333 & Barchanoid \\
\hline
\end{tabular}


Table 3: N2, Second Sand Dunes Patch along Nubra River

\begin{tabular}{|c|c|c|c|c|c|c|}
\hline Sr. No. & Length (m) & Wridth (m) & Height (m) & Area (Sq m) & Perimeter (m) & Type \\
\hline 1 & 388.69 & 1245.77 & 32.80 & 347,885 & 2,761 & LINEAR/DISTURBED \\
\hline
\end{tabular}

Table 4: S1 Sand dunes Patch along Shyok River

\begin{tabular}{|c|c|c|c|c|c|c|}
\hline Sr. No. & Length (m) & Wridth in (m) & Height (m) & Area (Sq m) & Perimeter (m) & Type \\
\hline 1 & 231.05 & 279.72 & 9.00 & 27,403 & 924 & Barchanoid Type \\
\hline 2 & 199.18 & 362.2 & 15.67 & 34,508 & 1,058 & Barchanoid Type \\
\hline 3 & 222.37 & 438.02 & 16.00 & 36,718 & 1,294 & Barchanoid Type \\
\hline 4 & 64.1 & 459.56 & 39.33 & 32,412 & 1,183 & Barchanoid Type \\
\hline 5 & 112.91 & 393.52 & 51.33 & 28,142 & 1,008 & Barchanoid Type \\
\hline 6 & 127.03 & 404.15 & 34.00 & 39,322 & 1,132 & Barchanoid Type \\
\hline 7 & 79.17 & 449.77 & 34.00 & 37,145 & 1,197 & Barchanoid Type \\
\hline 8 & 85.7 & 180.17 & 6.67 & 12,035 & 484 & Barchanoid Type \\
\hline 9 & 94.06 & 466.96 & 5.33 & 30,704 & 1,208 & Barchanoid Type \\
\hline 10 & 68.32 & 157.51 & 6.00 & 7,733 & 422 & Barchanoid Type \\
\hline 11 & 70.52 & 215.64 & 13.00 & 11,367 & 554 & Barchanoid Type \\
\hline 12 & 165.57 & 391.87 & 11.33 & 32,157 & 1130 & Barchanoid Type \\
\hline 13 & 177.68 & 898.89 & 11.00 & 69,913 & 2194 & Barchanoid Type \\
\hline 14 & 235.12 & 409.58 & 7.00 & 91,409 & 1,555 & Barchanoid Type \\
\hline 15 & 199.84 & 1910.27 & 15.67 & 247,239 & 4,512 & Barchanoid Type \\
\hline 16 & 91.83 & 1424.09 & 11.00 & 128,692 & 3,543 & Barchanoid Type \\
\hline 17 & 121.02 & 369.39 & 7.67 & 28,142 & 930 & Barchanoid Type \\
\hline 18 & 95.35 & 443.23 & 8.67 & 28,846 & 1,116 & Barchanoid Type \\
\hline 19 & 106.93 & 875.99 & 11.33 & 53,947 & 2,191 & Barchanoid Type \\
\hline 20 & 86.62 & 679.93 & 9.33 & 46,497 & 1,657 & Barchanoid Type \\
\hline 21 & 68.12 & 128.43 & 6.00 & 5,312 & 375 & Barchanoid Type \\
\hline 22 & 83.09 & 142.37 & 7.00 & 5,417 & 410 & Barchanoid Type \\
\hline 23 & 60.24 & 464.27 & 20.05 & 36,852 & 1,396 & Barchanoid Type \\
\hline 24 & 108.99 & 400.14 & 9.33 & 35,559 & 1,136 & Barchanoid Type \\
\hline 25 & 58.25 & 217.45 & 12.00 & 11,302 & 604 & Barchanoid Type \\
\hline 26 & 77.62 & 215.57 & 13.67 & 15,547 & 643 & Barchanoid Type \\
\hline 27 & 72.74 & 158.35 & 11.00 & 12,532 & 522 & Barchanoid Type \\
\hline 28 & 121.52 & 816.05 & 14.67 & 77,847 & 2,071 & Barchanoid Type \\
\hline 29 & 72.51 & 482.41 & 15.67 & 31,676 & 1,153 & Barchanoid Type \\
\hline 30 & 31.34 & 235.8 & 10.67 & 6,755 & 551 & Barchanoid Type \\
\hline 31 & 71.98 & 389.74 & 17.67 & 19,664 & 889 & Barchanoid Type \\
\hline
\end{tabular}




\section{Sand Dunes along the Shyok River in Hunder}

The SD were studied in four patches, named S1, S2, S3 and S4, in Hunder area along the Shyok River. The length of SD in Hunder area ranges from $14.44 \mathrm{~m}$ to 232.12
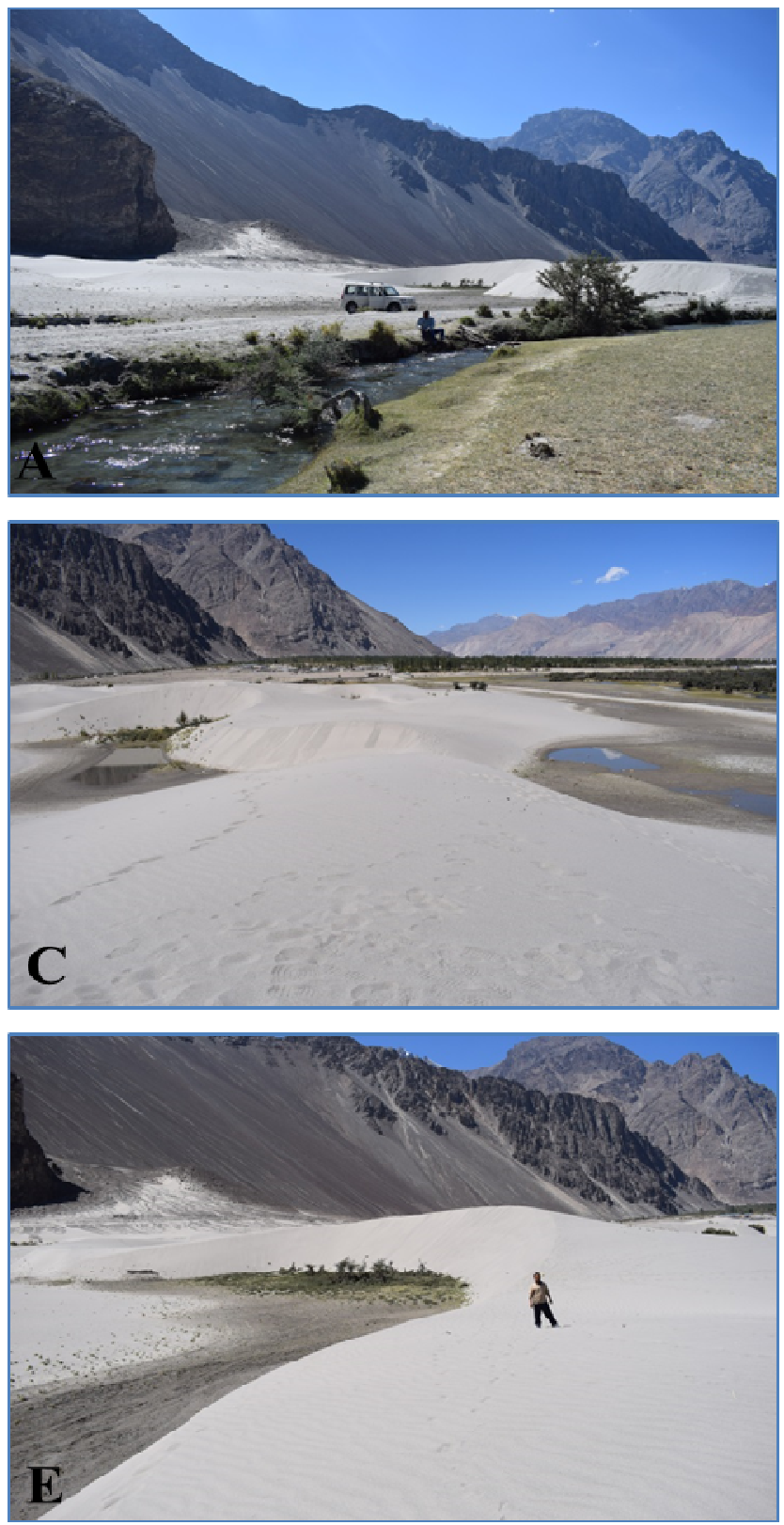

$\mathrm{m}$, breadth 46.28 to $1910.27 \mathrm{~m}$ and height 1.33 to $51.33 \mathrm{~m}$. In another place along the Shyok River, SD are located in three patches and all are barchanoid type (Table 4, 5, 6 \& 7).
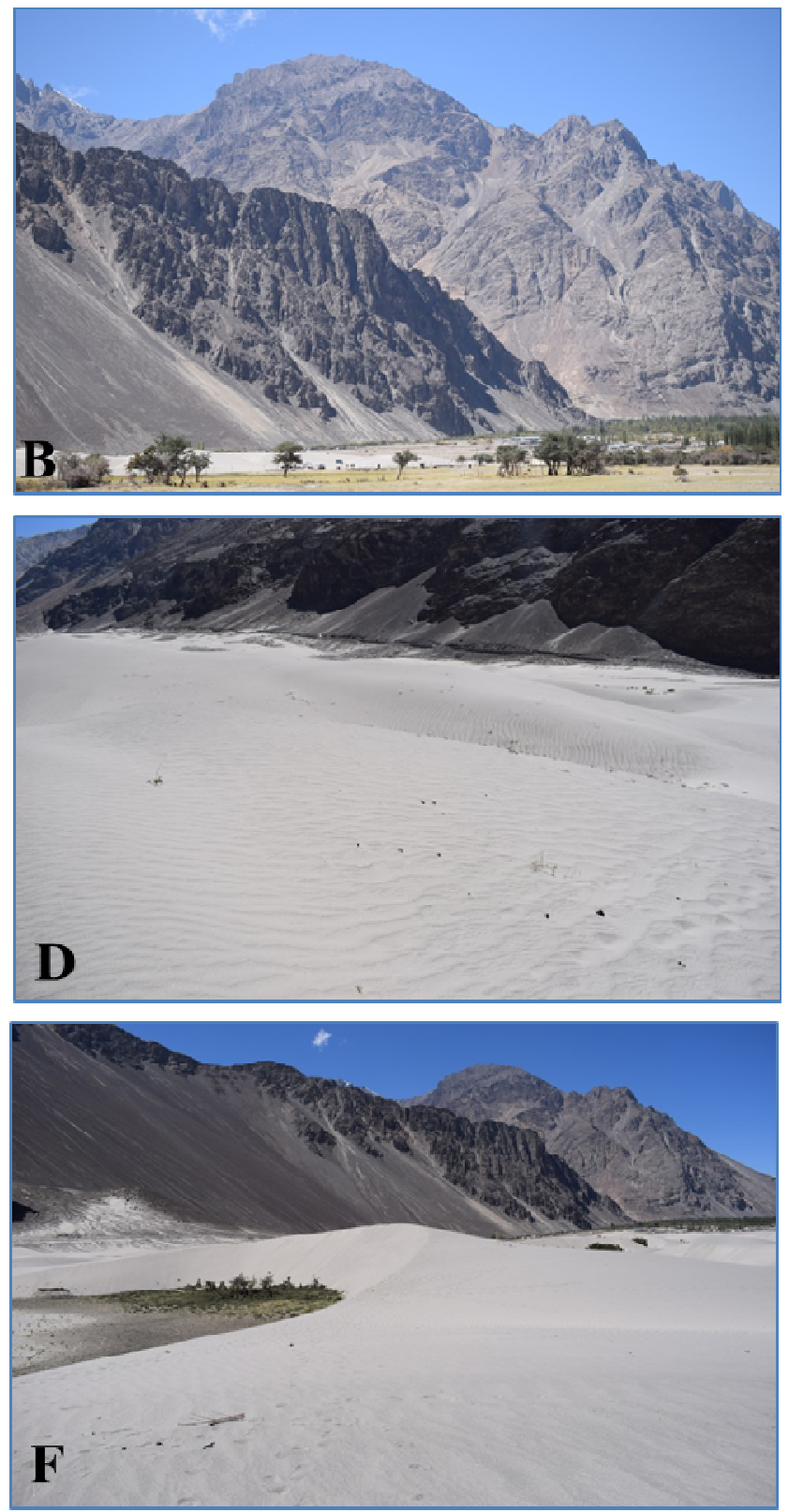

Figure 3: Sand Dunes in Hunder Area (A) Sand dune carpeting bounded by hill slope and stream course. (B) Sand Dunes covered with Vegetation (C) Sand Dunes with inter sandunal lakes (D) Sand dunes showing ripple marks. (E) Typical barchanoid type sand dunes (F) Sharp edges though margin blunt in Barchanoid 
Table 5: S2 Sand Dunes patch along Shyok River

\begin{tabular}{|c|c|c|c|c|c|c|}
\hline Sr. No. & Length (m) & Wridth (m) & Height (m) & Area (Sq m) & Perimeter (m) & Type \\
\hline 1 & 115.38 & 247.97 & 10.90 & 23,043 & 666 & Barchanoid Type \\
\hline 2 & 81.19 & 326.64 & 10.50 & 21,714 & 812 & Barchanoid Type \\
\hline 3 & 70.71 & 438.28 & 19.50 & 31,944 & 1,060 & Barchanoid Type \\
\hline 4 & 62 & 148.17 & 25.77 & 6,454 & 361 & Barchanoid Type \\
\hline 5 & 84.42 & 433.8 & 23.60 & 31,193 & 1,087 & Barchanoid Type \\
\hline 6 & 79.26 & 486.08 & 25.79 & 32,503 & 1247 & Barchanoid Type \\
\hline 7 & 72.09 & 227.57 & 18.20 & 15,541 & 657 & Barchanoid Type \\
\hline 8 & 44.81 & 217.2 & 14.37 & 9,191 & 530 & Barchanoid Type \\
\hline 9 & 42.69 & 412.4 & 13.70 & 29,107 & 1,076 & Barchanoid Type \\
\hline 10 & 56.28 & 409.55 & 42.00 & 26,373 & 1,082 & Barchanoid Type \\
\hline 11 & 145.63 & 459.91 & 24.20 & 48,591 & 1,382 & Barchanoid Type \\
\hline 12 & 29.89 & 185.44 & 13.07 & 4,949 & 429 & Barchanoid Type \\
\hline 13 & 50.71 & 97.71 & 5.67 & 3,033 & 235 & Barchanoid Type \\
\hline 14 & 90.68 & 194.94 & 24.67 & 11,785 & 578 & Barchanoid Type \\
\hline 15 & 65.36 & 376.72 & 29.00 & 26,199 & 1,020 & Barchanoid Type \\
\hline 16 & 77.49 & 503.48 & 11.33 & 40,899 & 1,444 & Barchanoid Type \\
\hline 17 & 68.72 & 1055.72 & 5.00 & 75,259 & 2,501 & Barchanoid Type \\
\hline 18 & 77.22 & 371.77 & 17.33 & 23,487 & 949 & Barchanoid Type \\
\hline 19 & 42.49 & 81.98 & 1.49 & 2,859 & 236 & Barchanoid Type \\
\hline 20 & 34.59 & 139.77 & 6.33 & 5,400 & 378 & Barchanoid Type \\
\hline 21 & 34.52 & 144.75 & 9.33 & 3,469 & 346 & Barchanoid Type \\
\hline 22 & 41.37 & 146.49 & 23.00 & 4,881 & 453 & Barchanoid Type \\
\hline 23 & 32.92 & 110.46 & 20.20 & 3,236 & 292 & Barchanoid Type \\
\hline 24 & 81.33 & 218.14 & 14.00 & 16,279 & 660 & Barchanoid Type \\
\hline 25 & 24.15 & 239.16 & 19.00 & 7,195 & 551 & Barchanoid Type \\
\hline 26 & 121.09 & 679.73 & 28.70 & 53,929 & 1,604 & Barchanoid Type \\
\hline 27 & 94.46 & 569.45 & 34.33 & 42,759 & 1,414 & Barchanoid Type \\
\hline 28 & 68.47 & 170.91 & 32.00 & 8,577 & 414 & Barchanoid Type \\
\hline 29 & 58.69 & 233.11 & 40.00 & 9,133 & 541 & Barchanoid Type \\
\hline 30 & 19.84 & 64.46 & 47.33 & 842 & 146 & Barchanoid Type \\
\hline 31 & 21.54 & 46.28 & 30.87 & 666 & 116 & Barchanoid Type \\
\hline 32 & 26.33 & 64.41 & 43.33 & 1,124 & 153 & Barchanoid Type \\
\hline 33 & 31.67 & 75.58 & 20.67 & 1,704 & 185 & Barchanoid Type \\
\hline 34 & 34.65 & 177.95 & 7.13 & 2,743 & 398 & Barchanoid Type \\
\hline 35 & 35 & 187.19 & 45.00 & 7,495 & 480 & Barchanoid Type \\
\hline 36 & 28.54 & 117.11 & 36.33 & 2,893 & 289 & Barchanoid Type \\
\hline 37 & 14.44 & 110.79 & 23.17 & 1,990 & 280 & Barchanoid Type \\
\hline 38 & 30.74 & 88.53 & 20.37 & 2,061 & 229 & Barchanoid Type \\
\hline
\end{tabular}


Table 6: S3 Sand Dunes Patch along Shyok River

\begin{tabular}{|c|c|c|c|c|c|c|}
\hline Sr. No. & Length (m) & Wridth in (m) & Height (ft) & Area (Sq m) & Perimeter (m) & Type \\
\hline 1 & 47.93 & 52.34 & 1.33 & 2,898 & 224 & Barchan Type \\
\hline 2 & 40.79 & 61.9 & 8.00 & 1,835 & 189 & Barchan Type \\
\hline 3 & 48.31 & 53.32 & 6.00 & 2141 & 193 & Barchan Type \\
\hline 4 & 72.24 & 101.35 & 6.67 & 3,238 & 273 & Barchan Type \\
\hline
\end{tabular}

Table 7: S4 Sand Dunes Patch along Shyok River. The dunes presented in Table 7 are highly disturbed but we classified them in brachanoid type

\begin{tabular}{|c|c|c|c|c|c|c|}
\hline Sr. No. & Length (m) & Wridth in (m) & Height (ft) & Area (Sq m) & Perimeter (m) & Type \\
\hline 1 & 132.55 & 127.94 & 3.33 & 7,402 & 459 & Barchan Type \\
\hline 2 & 104 & 105 & 8.33 & 6,911 & 388 & Barchan Type \\
\hline 3 & 187.28 & 200.34 & 5.00 & 17342 & 661 & Barchand Type \\
\hline 4 & 113.51 & 98.69 & 3.00 & 7,016 & 349 & Barchan Type \\
\hline
\end{tabular}

Three geomorphic processes, viz. glacial, fluvial and aeolian, appears to have played key role in formation of SD in river beds of the Ladakh area. However, abundance of wind-generated ripple marks reveals dominance of aeolian action in genesis of SD. In fact, the presence of Barchans type of SD suggests that wind was mostly unidirectional during formation of barchans dunes in the area (Hatano and Hatano, 2001) (Figure 2 and 3). Barchans type of SD are formed where there is a limited supply of sand, having flat ground, in which wind blows in one direction (Pidwirny, 2015). As merging of two or more barchans were commonly seen, barchans of the area have been categorized as barchanoid type of sand dunes (Tables 2 and 4). Wherever their morphology has been obliterated by river actions their shape is disturbed. Longitudinal dunes are rarely observed in the area. However, morphology of longitudinal dunes suggests that their formation may be related to multidirectional wind regime.

The carpeting of sand in the hill slope may be linked with funneling of winds towards lower section of hill ranges, swiping sand along with them and dropping with subsidence when they hit hill leading to sand carpeting of the varying thickness in hill slopes. It was also observed that the majority of dunes are present in the vicinity of granitic terrain, which may be due to supply of sands from such rocks. This is further supported by mineralogy through XRD studies. The XRD of sediments suggests quartz is the dominant phase followed by feldspar, biotite and chlorite, with occasional hornblende and heavy mineral assemblage of zircon, rutile, sphene and ilmenite. This mineral assemblage is more akin to granitic suite of rocks. Therefore lithology of sand dunes appears to be controlled by litho units of the region, especially granitic rocks. Thus, in a nutshell, results of this study suggest that the formation of sand dunes in the Ladakh area is controlled by lithology and geomorphic agents, with dominance of aeolian processes relative to fluvial and glacial processes.

\section{ACKNOWLEDGEMENT}

The first author (NS) thanks DST funding through young scientist scheme (YSS/2015/001185) for proving funds for the present study.

\section{REFERENCES}

Bagati T.N. and Thakur V.C., 1993. Quaternary basin of Ladakh and LahulSpiti in northwestern Himalaya. Current Science, 64(11\&12): 898-903.

Bullard J.E. and Livingstone I., 2002. Interactions between aeolian and fluvial systems indryland environments. Area, 34(1): 8-16.

Bullard J.E. and McTainsh G.H., 2003. Aeolian-fluvial interactions in dryland environments: examples, concepts and Australia case study. Prog. Phys. Geogr., 27(4): 471-501. 
Charlton R., 2008. Fundamentals of Fluvial Geomorphology. Routledge, London and New York.

Derbyshire E. and Owen L.A., 2017. Glacioaeolian Processes, Sediments, and Landforms. In Past Glacial Environments (Second Edition), pp. 273308.

Han G., Zhang G. and Dong Y., 2007. A model for the active origin and development of source-bordering dunefields on a semiarid fluvial plain: a case study from the Xiliaohe Plain, Northeast China. Geomorphology, 86(3-4): 512-524.

Maroulis J.C., Nanson G.C., Price D.M. and Pietsch T., 2007. Aeolian-fluvial interaction and climate change: source-bordering dune development over the past $100 \mathrm{ka}$ on Cooper Creek, central Australia. Quat. Sci. Rev., 26(3-4): 386-404.

Lancaster N., 2011. Desert dune processes and dynamics. Arid zone geomorphology: process, form, and change in drylands. Wiley

Leopold L.B. and Wolman M.G., 1957. River channel patterns: braided, meandering and straight. Geological Survey professional paper; no. 282-B. U.S. Dept. of the Interior, Washington.

Li S., Dong G., Shen J., Yang P., Liu X., Wang Y., Jin H. and Wang Q., 1999. Formation mechanism and development pattern of aeolian sand landform in Yarlung Zangbo. River valley. Sci. China Ser. D Earth Sci., 42(3): 272-284.

Liu L.Y., Skidmore E., Hasi E., Wagner L. and Tatarko J., 2005. Dune sand transport asinfluenced by wind directions, speed and frequencies in the Ordos Plateau, China. Geomorphology, 67(3-4): 283297.

Liu B. and Coulthard T.J., 2015. Mapping the interactions between rivers and sand dunes: Implications for fluvial and aeolian geomorphology. Geomorphology, 231: 246-257.

Langford R.P., 1989. Fluvial-aeolian interactions: Part I, modern systems. Sedimentology, 36(6): 10231035 .

Loope D.B., Swinehart J.B. and Mason J.P., 1995. Dunedammed paleo valleys of the Nebraska Sand Hills: intrinsic versus climatic controls on the accumulation of lake and marsh sediments. Geol. Soc. Am. Bull., 107(4): 396-406.

Pidwirny M., 2015. Understanding Physical Geography, 1st Edition. Date Viewed. http://www.physical geography.net/understanding/contents.html

Song Y., Yan P. and Liu L., 2006. A review of the research on complex erosion by wind and water. J. Geogr. Sci., 16(2): 231-241.

Sweet M.L., Nielson J., Havholm K. and Farrelley J., 1988. Algodones dune field of Southeastern Californiacase-history of a migrating modern dune field. Sedimentology, 35(6): 939-952.

Xu J., Yang J. and Yan Y., 2006. Erosion and sediment yields as influenced by coupled eolian and fluvial processes: the Yellow River, China. Geomorphology, 73(1-2): 1-15.

Hatano Y. and Hatano N., 2001. Dune Morphology and Sand Transport. Forma, 16: 65-75. 